\title{
在革命化的大道上我国气象工作的飞跃发展
}

\author{
顾 震 潮
}

回想建国十五周年以来，我国气象工作 方面的发展，也和其他各个战綫上一样，取 得了巨大的成就和飞跃的进步，与解放以前 相比，真是不可同日而語的。

气象工作是以覌測为基础的。不論是单 站补充預报还是数值天气預报，不諭是农业 气候服务还是航空天气实况服务, 都只有依 据实际气象情况，都少不了气象覌測。一个 国家如果沒有自己的广大、細密、可靠而現 代化的气象覌測, 一切气象业务、气象研究、 气象教育等等都要落空。

我們知道天气变化各地不同, 因此, 要 了解天气, 就要在各地設气象台、站。要了 解得更具体、更詳細，气象台、站就要設得 更密。解放后，我們的气象台、站已增加了 二十多倍。为天气預报发报的气象台、站也 已增加了十倍左右, 不但地面上的气象覌測 增加了, 并且对高空的气球覌測也大大增加 了。我国大部分地区气象网現在已經与世界 上气象台、站稠密的地区一样密了。建立起 这么多气象台、站, 在資本主义国家大約要 半个世紀。在国际上，天气覌測大約最多每 十年增加一倍，平均来說还不到这个速度。 而我們在解放以后的长时間里,保持了以二、 三年就增加一倍的速度, 象这样高速度地建 立大批气象台、站,是世界气象工作上少有的 事。这是我国气象工作的一个很大的成績。
我們不但在一般的地区气象台、站增加 得很快，而且在我国边远地区气象台、站也 增加得很快。这更是突出的事。解放前，象 青藏高原上这样广大的地区，在天气覌測上 可以說是一片空白，以致删时往待把天气图 的范围只包括到东經 100 度的地区。外国的 “探险队”、“考察队”在我国的靑海、西藏、 新疆一带进行偷偷的非法活动，他們測得的 一些片断的气象資料，就被看成难得的宝貝 了。往往只凭那些地方几个月乃至几十天的 天气观測就作起天气研究来。然而現在我們 在广大的边远地区，已建立起許多气象台、 站。有的測站海拔高度有 5000 米，可以說 是世界上最高的气象台站。实际上不要說在 今天，就是早在十年前这种情况就已經引起 了外国气象工作者的惊奇。的确，这只能是 解放后才能做到的事。我們的气象台、站不 但在数量上有飞跃的发展，就是在稹量上与 解放前比也是大大不同了。年紀大一些的气 象工作者都还記得, 在解放前, 气象仪器不 但是絕大多数靠从国外进口，乎且对这些气 象仪器不加检定就使用。因此, 不必說那种 伪浩紀录的事，就是真实的覌測，也是不精 确的。这种情况現在看来是不可理解的，但 在解放前却是普遍的。在解放后不久，我們 就建立了气象仪器检定工作。所有温度、气 压、湿度、风速、輻射等等都已建立了检定 
仪器的設备, 普遍作了检定。

不但如此，这些气象台、站日常观測用 的气象仪器，也都是由我們自己設計制造的。 象气球探測用的探空仪 (59型)就是自己設計 制造的新型仪器。这种气象探空仪比起过去 我們所使用的同类外国仪器更为牢靠、准确。 这是气象工作在自力更生方針的指引下所取 得的又一成績。

除了日常的气象覌測外，在稹的方面来 說, 我們也提高了专門覌測, 例如小气候覌 測、农业气象覌測，特別是大气物理的观 測。1958 年大跃进以来, 由于人工降水的 带动, 我国气象工作者設計制造了一些云雾 物理的仪器, 在高山上、本地上和飞机上等 进行了好儿种云雾物理覌測，包括云滴譜、 含水量、唀明度、盐核等等覌測。为了雷电 的偵察定位，我們也开展了雷电的覌測，包 括用气象雷达、雷电指示器等仪器的覌測。 一些气象实驗研究室象㸴究雷电用的高电压 实驗室、云雾物理实驗室、模拟实驗室等也 都建立起来了。为了祖国气象覌測和仪器的 发展, 为了祖国气象工作的进一步发展, 这 些实驗气象学的工作是很重要的工作。它是 我国气象科学上大跃进以来的新收获之一。

这些工作是怎样才出色地完成的呢? 我 想, 有不少原因。而其中很重要的一个因㴒 就是人的革命化。我們人民的气象工作是革 命的气象工作。革命的气象工作不但要为革 命服务, 并且要在党的方猃、政策下, 用革 命的办法由革命化的人来干。汶里限于篇 幅, 只想指出人的革命化特別重要。单就进 行气象观測来說, 气象观測看来似乎多么平 凡, 多么单調, 年复一年、日日夜夜就守着 这几支温度表、气压表, 更不必說在边远地 区，象孤島、高山、沙漠、荒原，甚至百里
以內沒有人烟，气候等自然条件十分昰劣。 在这些条件下,看到了气象覌測的重要意义, 看到了祖国在农业、航空等各方面的迫切需 要, 派到那里就在那里观測, 坚守气象滴 位，刻苦鉆研，主动作許多服务工作，作得 很出色。現在在我們的气象台、站中已經出 現了大批的先进台、站和先进工作者。例如 在去年河北省大洪水时，有的气象站已被很 深的洪水包围, 四周只見猛烈的风浪, 情况 险恶，而他們在覌測場上坚持到最后一分鈡。 广东海边的一个气象工作人員为了不耿誤拍 发气象覌測电报，在电綫中断、沒有交通工 具的情况下，冒着五級风浪，游过广闊的海 峽运出了气象观測电报。在福建高山上的观 測員, 在哚夜三点电話綫断了的时候, 他們 不管严冬夜里的黑暗寒冷，不管遍山的雨淡 和冰雪, 一步一滑地在山岩上一里一里地检 查綫路, 終于查出了断綫, 用冻㯖的手指接 好了电綫，发出了气象观測电报。在內蒙十 分荒涼的戈壁滩上，一个气象站在持久的大 风雪里不但克服了喼外的缺根断炊的困难, 千方百計地維持测报, 还掛出灯光訊号, 营 救了迷路的牧民。他們所以能作得十分出 色，就是凭了全心全意为人民服务的思想， 扰莽一切个人考虑的革命志向，凭工作同志 的阶級覚悟。我們的气象观測工作者是把气 象观測当做革命工作、作为伟大社会主义事 业的一部分来完成的。

䛍到专門观測和实驗也是一样。这些工 作往往是气象呼究工作者的任务, 而在旧中 国, 象其他科学研究一样, 气象研究的最后 目标照例是发表論文，取得个人名位，至于 这工作是否需要，究竟能起多大作用，如何 实現、使用是不感兴趣的。因此总是挑最不 費劲的工作来做。比較起来, 气象覌測实驗 
是要費放得多的，条件䚁可能不完全具备、 工作也不象有些工作那样 “省放” (甚至閉門 讀书、大笔一揮就可以成文的)，野外覌測 生活条件就必然差些, 工作也必然更劳累 些, 就是实驗室也总不会象拈房、办公室那 样安靜、舒服和安全。然而沒有这些工作, 我們的气象学也就不会有审固的科学实驗基 础。因此进行这些工作首先就得要看到祖国 气象事业的需要, 世界革命的需要, 王弃自 已个人主义的研究动机, 不考虑能不能发表 論交, 不考虑影响不影响升級, 不考怎別人 如何估計自己, 踏踏实实, 从无到有, 克服
各种困难, 使实驗气象学能为气象探測等需 要而建立起来。也就是說, 必須不断解决人 的革命化的問題。

在其他方面我們的气象工作也由于革命 化而取得了許多成就，这里就不細說了。

当然, 我們的气象工作也还远赶不上需 要, 气象覌測和实驗与其他方面比較起来更 还是一个比較薄弱的环节。但在党和政府的 正确領导下, 只要自覚地使自己不断地革命 化, 我們气象工作者一定能信心百倍、接受 更艰巨的任务, 向着更高的目标努力, 取得 远为巨大的成就。

\section{听毛主席的話 走革命的道路}

\section{侯 仁之}

祖国伟大的社会主义建設，在极为广闊 的現代科学領域里提出了无数的新任务和新 課題, 从根本上推动着所有学科一一特別是 一些薄弱以及空白学科的迅速成长和发展, 这是我国科学史上空前未有的黃金时代。在 这庆视建国十五周年的时候，作为一个科学 工作者不能不感到无比的欢欣和鼓舞!

但是，作为一个来自旧社会的人，我深 梁体会到自己升不是一下子就能够訩識到这 个伟大的科学史上的新时代以及它所包含的 哚刻涵义的。为什么是这样的呢? 我想这首 先是因为自己是在一种完全不同的“教养”中 成长起来的。在那种“教养”中，科学研究看 作是一种超然的、个人的精神活动, “为科学
而科学” 被訩为是科学工作者的共同信条。 其次是自己在科学䂰究的道路上也已經走过 了或长或短的一段, 并且自訩为找到了一个 值得沉緬于其中的工作領域，培养了自己一 定的兴趣和爱好, 是甘心乐意在这个方向上: 終其一生的。实际上这就是說, 一套完整的 学术覌点和治学方法在自己的生活里已經根 媣蒂固。自然，起初我我不訩識这就是資产 阶級世界覌在我的学术生活里的具体表現, 而这种世界覌說穿了就是它只能使我把个人 的兴趣和志愿放在实际的客覌需要之上, 把 个人的业务成就看得更高于革命的要求。在 这种世界覌的支配下又哪里能够, 看到这新时 代的伟大意义？又哪里能够勇往值前地承担 